\title{
Cystic Fibrosis in Europe - remote measurement of outcome
}

\author{
Anil Mehta ${ }^{1 *}$, Gita Mehta ${ }^{1}$, Milan Macek ${ }^{2}$ \\ From 5th European Conference on Rare Diseases (ECRD 2010) \\ Krakow, Poland. 13-15 May 2010
}

\section{Background}

Cystic Fibrosis (CF) occurs randomly in children across all European social strata providing an opportunity to sample their underpinning health care provision for this rare disease in an unbiased manner. We developed a 35 country European cystic fibrosis (CF) demographic registry to compare CF outcomes through an FP6 programme of the EU called EuroCareCF (http://www. eurocarecf.eu).

\section{Methods}

We applied methods (http://www.cystic-fibrosis.org.uk) previously used to create country-specific registries after inviting participation through the European CF Society and CF patient organisations using a double hub (Dundee and Prague) and spoke model supplemented by conferences, workshops and telephone support using a single data collection system. Implementing this common data collection platform, we collated demographic and genotype data in around 30,000 patients scattered from Iceland to the Black Sea.

\section{Results}

Amongst the $\sim 30,000$ CF patients in our Registry, a widely different country-specific prevalence of childhood $\mathrm{CF}$ exists that cannot be explained by differences in population size, underlying heterozygote $\mathrm{CF}$ gene frequency or under-ascertainment. In particular, we do not believe that the lattermost can explain our findings because in late childhood, we observe a significant paucity of the clinically severe homozygous F508-del form of CF that is of early childhood onset in $90 \%$ of cases and is widely dispersed across mainland Europe.

\footnotetext{
*Correspondence: a.mehta@dundee.ac.uk

'Division of Medical Sciences, University of Dundee, Ninewells Hospital Medical School, Dundee DD1 9SY Scotland, UK

Full list of author information is available at the end of the article
}

\section{Conclusions}

It is likely that an excess premature CF mortality in childhood still occurs across many parts of Europe, a mortality that has largely disappeared in countries such as the UK, France Germany and other wealthy nations. We suggest that much of (better resourced) Western Europe now has a vanishingly low mortality for the severe commonly occurring F508del homozygous CF in childhood that is not replicated in our study in many European countries. The reasons require investigation.

\section{Author details}

${ }^{1}$ Division of Medical Sciences, University of Dundee, Ninewells Hospital Medical School, Dundee DD1 9SY Scotland, UK. '2Department of Biology and Medical Genetics, Charles University Prague- Second, Faculty of Medicine and University Hospital, Motol, Prague, Czech Republic.

Published: 19 October 2010

doi:10.1186/1750-1172-5-S1-P6

Cite this article as: Mehta et al:: Cystic Fibrosis in Europe - remote measurement of outcome. Orphanet Journal of Rare Diseases 2010 5(Suppl 1):P6.

Submit your next manuscript to BioMed Central and take full advantage of:

- Convenient online submission

- Thorough peer review

- No space constraints or color figure charges

- Immediate publication on acceptance

- Inclusion in PubMed, CAS, Scopus and Google Scholar

- Research which is freely available for redistribution

Submit your manuscript at www.biomedcentral.com/submit
Biomed Central 